\title{
ANK1 Gene
}

National Cancer Institute

\section{Source}

National Cancer Institute. ANK1 Gene. NCI Thesaurus. Code C84301.

This gene plays a role in red blood cell morphology. 